\title{
SENTINEL LYMPH NODE BIOPSY AFTER NEOADJUVANT CHEMOTHERAPY. IT IS WORTH TO DECIDE!
}

\author{
Agnė Čižauskaitė ${ }^{1,2}$, Donatas Petrauskas ${ }^{1}$, Dainius Šimčikas ${ }^{2,3}$, Alvydas Česas $^{1}$ \\ ${ }^{1}$ Klaipeda University Hospital, Oncology Chemotherapy Clinic, Klaipeda, Lithuania, \\ ${ }^{2}$ Klaipeda University, Faculty of Health Sciences, Nursing Cathedral, Klaipeda, Lithuania, \\ ${ }^{3}$ Klaipeda University Hospital, Abdominal and Endocrine Surgery Clinic, Klaipeda, Lithuania
}

Key words: breast cancer, sentinel lymph node, neoadjuvant chemotherapy, axillar lymph node dissection.

\section{Summary}

Objective. To evaluate the predictable percentage of patients that could be eligible for sentinel lymph node biopsy (SLNB) after neoadjuvant chemotherapy (NAC) in Klaipeda University Hospital Breast Surgery Department.

Background. Although SLNB is a standard staging method for axillar node status assessment for early-stage clinically lymph node (LN) negative breast cancer patients, SLNB after NAC is still controversial. Axillary lymph node dissection (ALND) still remains standard accepted surgical approach for patients following NAC regardless of primary LN status. ALND is associated with significant morbidity and complications. NAC is now used with increasing frequency not only for locally advanced but also for early-stage breast cancer and optimal indications for SLNB after NAC are required.

Methods. 163 cases with breast cancer treated by NAC were enrolled in this study. After NAC all patients at the time of definitive breast surgery, underwent ALND.

Results. Before NAC, clinical LN status was negative in 21 cases (13\%) and positive in $141(87 \%)$. When evaluated postoperatively, pN0 in clinically LN negative group was detected in 21 patients $(100 \%)$. Meanwhile in clinically LN positive group, pN0 was $63(44.7 \%)$ and $\mathrm{pN}+78(55.3 \%)$ of cases. Conclusions. SLNB should always be performed before or after NAC in clinically LN negative patients. Optimal technique should be chosen in node-positive patients to assure the success of the procedure.

\section{Introduction}

Breast cancer (BC) is the most commonly diagnosed type of cancer in women worldwide counting around 464 (28.8\%) expected new cases per 100.000 in Europe [1].

Axillary-lymph-node status is one of the most important prognostic predictors for breast cancer patients guiding loco-regional and systemic treatment decisions [2].

Assessment of lymphatic mapping and sentinel lymph node biopsy (SNB) is now used to determine axillary node status as a 'golden standard' for patients with early-stage breast cancer with clinically negative axillary lymph nodes [3].

In 1955, for the first time lymphatic mapping was presented by Seaman and Powers using radiolabeled colloidal gold to describe the path of lymphatic channels followed by cancer [4]. 'Sentinel lymph node' was defined as the first node to be involved in lymphatic spread by Gould et al in 1960 [5]. Finally, in 1992 Morton et al showed that SLN could accurately predict the potential for cancer in the associated basin [6].

Neoadjuvant chemotherapy (NAC) is now used with increasing frequency not only for locally advanced but also for early stage breast cancer [7]. NAC is known to extend the opportunity for breast conserving surgery, improve cosmesis, enable assessment of NAC response, allow to downstage of the axillary status and provide research opportunities to better understanding the biology of breast cancer [8].

Axillary lymph node dissection (ALND) still remains standard accepted surgical approach for patients following NAC regardless of primary lymph node status [9]. ALND is associated with significant morbidity and complications as lymphedema of the upper limb, pain, paresthesia, and restriction of motion of the shoulder girdle $[10,11]$.

The optimal timing of SNB for breast cancer patients after NAC is still controversial [12]. As reported in SENTINA trial, lower detection rate ant higher false-negative rate of SNB in patients group after NAC was determined 
[2]. According to other authors, the higher false negative rate and the lower feasibility and accuracy of this procedure may be due to possible alterations to intramammary lymphatic drainage, potential multiple obscured and undetected sources of lymphatic drainage for larger tumors and possible non-uniform cytotoxic responses of axillary metastases [13].

The aim of our retrospective study was to evaluate the predictable percentage of patients that could be eligible for SLNB after NAC in Klaipeda University Hospital Breast Surgery Department.

\section{Patients and methods}

From 2010 to 2014, 162 patients received NAC followed by breast surgery at Klaipeda University Hospital Breast Surgery Department. In all cases, the diagnoses were based on core needle biopsies before NAC. We allocated participants to two groups according to clinical (palpation and ultrasound) axillary node status before NAC (table 1).

All breast cancer patients were scheduled for neoadjuvant chemotherapy with the type and length of chemotherapy left to the discretion of the treating medical oncologist.

After completion of NAC at the time of definitive breast surgery, all patients underwent ALND.

\section{Results}

A total of 162 patients with breast cancer, who received NAC was selected for the retrospective study. Before NAC,

Table 1. Patient lymph node status characteristics

\begin{tabular}{|l|c|c|}
\hline \multirow{2}{*}{ Clinical LN status } & \multicolumn{2}{|c|}{ Patients (N=162) } \\
\cline { 2 - 3 } & $\mathbf{N}$ & $\mathbf{\%}$ \\
\hline $\mathrm{cN} 0$ & 21 & 13 \\
\hline $\mathrm{cN}+(\mathrm{cN} 1+\mathrm{cN} 2)$ & 141 & 87 \\
\hline
\end{tabular}

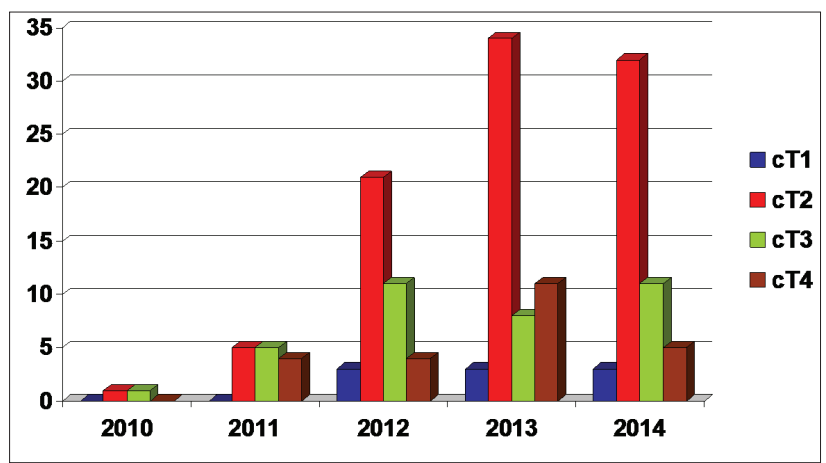

Figure 1. Tumor characteristics clinical LN status was negative in 21 cases $(13 \%)$ and positive in 141 (87\%).

According to clinical tumor status, 93 (57.4\%) women were T2, $36(22.2 \%) \mathrm{T} 3,24$ (14.8\%) T4 and 9 (5.5\%) T1 respectively (figure 1).

$75(46.3 \%)$ of patients underwent radical mastectomy, 63 (38.9\%) quadrantectomy, $15(9.3 \%)$ radical mastectomy with breast reconstruction, $9(5.5 \%)$ quadrantectomy with simultaneous mastopexy of the other breast or reconstruction followed by ALND (figure 2A and 2B).

When evaluated postoperatively, $\mathrm{pNO}$ in clinically
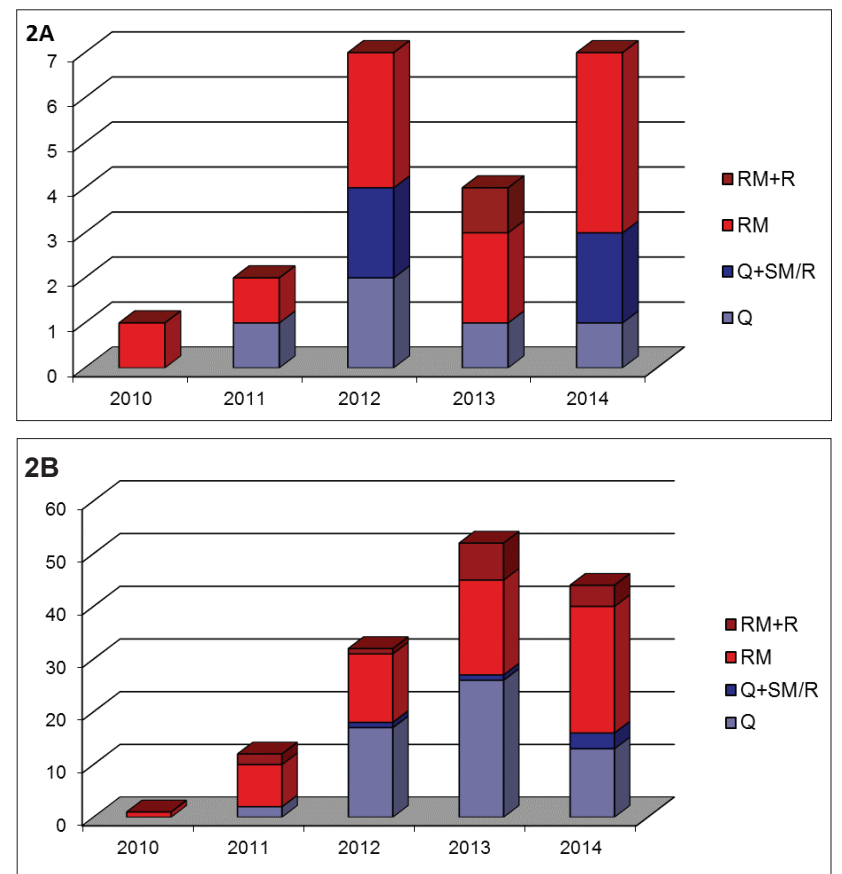

Figure 2. Surgical breast technique characteristics (2A - clinically LN negative patients, $\mathbf{2 B}$ - clinically node positive patients) Abbreviations: $R M$-radical mastectomy; $R M+R$-radical mastectomy with reconstruction;

$Q$-quadrantectomy; $Q+S M / R$-quadrantectomy with simultaneous mastopexy of the other breast/reconstruction.

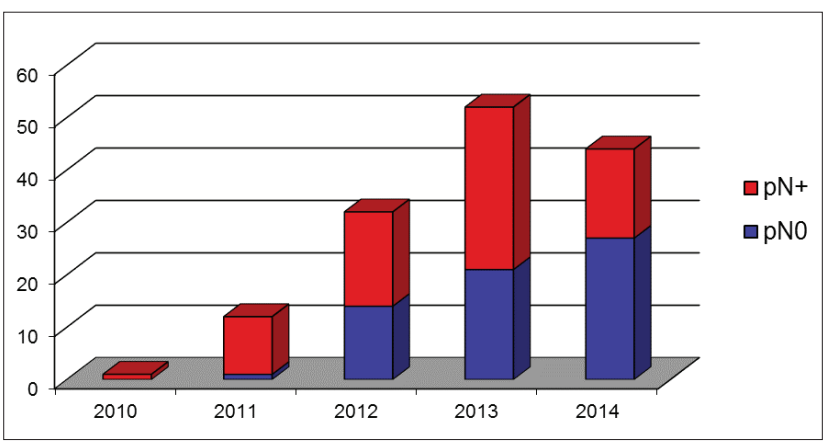

Figure 3. Pathological response characteristics 
LN negative group was detected in 21 patients $(100 \%)$. Meanwhile in clinically LN positive group, pN0 was 63 (44.7\%) and $\mathrm{pN}+78(55.3 \%)$ of cases (figure 3 ).

\section{Discussion}

The ipsilateral axillar LN site is the most common site for breast cancer metastases either it is the most important prognostic factor [11]. Although ALND facilitates staging and provides good regional control, it is also associated with severe morbidities of breast cancer surgery [10]. Up to $73 \%$ of patients undergoing ALND develop complications, such as nerve injury, restricted shoulder motion, arm weakness, and infections due to the number of lymph nodes removed [14]. SLNB is established as standard procedure for evaluation of axillary LN status in early breast cancer without clinical lymphadenopathy with minimal complication rate [15].

Since the usage of NAC is highly increased in earlystage and multifocal/-central breast cancer, the possibility of SLNB after NAC is widely discussed [16]. SLNB may now be offered in clinically LN negative breast cancer patients, however the usage in clinically LN positive patients is controversial [8]. In consent with other authors, pN0 in clinically LN negative group was detected postoperatively in $100.0 \%$ patients of our study. Nevertheless, ALND rates after NAC could be reduced because 20 to $40 \%$ of LN positive patients converts to LN negative at the time of operation [17]. Our study showed the same results in clinically LN positive group, $\mathrm{pN} 0$ was determined in $44.7 \%$ of cases.

Sentinel lymph node identification and false-negative (FN) rates in patients after NAC who initially had clinically node-positive breast cancer are the main aspects of concern [18]. NAC is thought to interfere with the anatomy and physiology of the lymphatic pathways by shrinkage and fibrosis of lymph vessels as well as obstructing them with cellular material or tumor emboli [13]. Therefore, according to the results of the studies of the American College of Surgeons Oncology Group (ACOZOG) Z1071 and SENTINA several suggestions are offered [2;3].

Reliability of SLNB, that is determined by sentinel node identification rate was $92.7 \%$ (ACOZOG Z1071) and $87.8 \%$ (SENTINA) in patients with initially LN positive disease $[2 ; 3]$. The accuracy of this procedure (e.g. falsenegative rate) was $14.2 \%$ [2].

Firstly, in the studies concerning SLNB after NAC, the use of dual tracers is strongly recommended [2,3]. The usage of dual mapping resulted a significant improvement in sentinel lymph node identification rate (93\% [ACOZOG Z1071] and $87.7 \%$ [SENTINA]) compared to single agent mapping (88.9\% [ACOZOG Z1071] and 77.4\% [SENTINA]) [2;3].
Either, the combined use of additional mapping agent decreased the FN rate from $16.0 \%$ (SENTINA) and $22.2 \%$ (ACOZOG Z1071) to $8.6 \%$ and $10.8 \%$ respectively [2].

Secondly, the significant relation between the number of sentinel nodes removed and the FN rate was established [18]. The FN rate was less than $10 \%$ for women who had three or more sentinel lymph node removed compared to $24.3 \%$ when one harvested [2].

Thirdly, the placement of the ultrasound (US) guided clips and wires at the time of suspicious lymph node biopsy may increase the accuracy of SLNB and evaluation of response to chemotherapy [19].

As the sentinel lymph node identification and FN rates in clinically node-positive breast cancer patients after NAC remain lower than in node-negative patients, the possibility of failure (to identify and to stage the axillary status) should be discussed and appropriate regional adjuvant treatment should be ensured.

\section{Conclusions}

In our study we have pointed out the results of LN status conversion after NAC. It is worth to decide performing SLNB after NAC in both clinically negative and positive patients. Optimal technique (dual mapping, more than three nodes removed and metastatic nodes marking before NAC) should be chosen in node-positive patients to assure the success of the procedure.

\section{References}

1. Ferlay J. et al. Cancer incidence and mortality patterns in Europe: estimates for 40 countries in 2012. Eur J Cancer 2013 Apr;49(6):1374-403.

http://dx.doi.org/10.1016/j.ejca.2012.12.027

2. Kuehn T. et al. Sentinel lymph-node biopsy in patients with breast cancer before and after neoadjuvant chemotherapy (SENTINA): a prospective, multicentre cohort study. Lancet Oncol 2013; 14:609-18.

http://dx.doi.org/10.1016/S1470-2045(13)70166-9

3. Boughey JC. et al. The role of sentinel lymph node surgery in patients presenting with node positive breast cancer (T0-T4, N1-N2) who receive neoadjuvant chemotherapy: results from ACOSOG Z1071 trial. Cancer Res 2012; 72(24):abstr 94s.

4. Seaman WB. et al. Studies on the distribution of radioactive colloidal gold in regional lymph nodes containing cancer. Cancer 1955; 8(5):1044-6.

http://dx.doi.org/10.1002/1097-0142(1955)8:5<1044::AIDCNCR2820080530>3.0.CO;2-6

5. Gould EA. et al. Observations on a sentinel node" in cancer of the parotid. Cancer 1960; 13:77-8.

http://dx.doi.org/10.1002/1097-0142(196001/02)13:1<77: :AID-CNCR2820130114>3.0.CO;2-D 
6. Morton DL. et al. Technical details of intraoperative lymphatic mapping for early stage melanoma. Arch Surg 1992; 127(4):392-9.

http://dx.doi.org/10.1001/archsurg.1992.01420040034005

7. Kaufmann. et al. Recommendation from an international expert panel on the use of neoadjuvant (primary) systemic treatment of operable breast cancer: new perspectives 2006. Ann Oncol 2007; 18:1927-34.

http://dx.doi.org/10.1093/annonc/mdm201

8. Lyman GH. et al. Appropriate role for sentinel node biopsy after neoadjuvant chemotherapy in patients with early-stage breast cancer. J Clin Oncol 2015; 33(3):232-4.

http://dx.doi.org/10.1200/JCO.2014.58.9838

9. Kida K. et al. A prospective feasibility study of sentinel node biopsy by modified Indigocarmine blue dye methods after neoadjuvant chemotherapy for breast cancer. Eur J Surg Oncol 2015; 41(4):566-70.

http://dx.doi.org/10.1016/j.ejso.2014.10.066

10. Helms G. et al. Shoulder-arm morbidity in patients with sentinel node biopsy and complete axillary dissection: data from a prospective randomised trial. Eur J Surg Oncol 2009; 35:697-701. http://dx.doi.org/10.1016/j.ejso.2008.06.013

11. Tan VK. et al. The feasibility and accuracy of sentinel lymph node biopsy in clinically node-negative patiens after neoadjuvant chemotherapy for breast cancer - a systematic review and meta-analysis. J Surg Oncol 2011; 104(1):97-103.

http://dx.doi.org/10.1002/jso.21911

12. Chung A. et al. Axillary staging in the neoadjuvant setting. Ann Surg Oncol 2010; 17(9):2401-10. http://dx.doi.org/10.1245/s10434-010-1001-8

13. Tsuyuki S. et al. Assessing the effects of neoadjuvant chemotherapy on lymphatic pathways to sentinel lymph nodes in cases of breast cancer: Usefulness of the indocyanine green-fluorescence method. Breast 2015; 24(3):298-301.

http://dx.doi.org/10.1016/j.breast.2015.02.034

14. Pecha V. et al. Sentinel lymph node biopsy in breast cancer patients treated with neoadjuvant chemotherapy. Cancer 2011; 15;117(20):4606-16.

15. Veronesi U. et al. Sentinel-node biopsy to avoid axillary dissection in breast cancer with clinically negative lymph-nodes. Lancet 1997; 349:1864-7. http://dx.doi.org/10.1016/S0140-6736(97)01004-0

16. Van der Heiden-van der Loo M. et al. Population based study on sentinel node biopsy before or after neoadjuvant chemotherapy in clinically node negative breast cancer patients: Identification rate and influence on axillary treatment. Eur J Cancer 2015; 51(8):915-21.

http://dx.doi.org/10.1016/j.ejca.2015.03.014

17. Janni W. et al. Sentinel node biopsy and axillary dissection in breast cancer - the evidence and its limits. Dtsch Arztebl Int 2014; 111(14): 244-9.
18. Zervoudis S. et al. Main controversies in breast cancer. World J Clin Oncol 2014; 5(3):359-73.

http://dx.doi.org/10.5306/wjco.v5.i3.359

19. Plecha D. et al. Improving the accuracy of axillary lymph node surgery in breast cancer with ultrasound-guided wire localization of biopsy proven metastatic lymph nodes. Ann Surg Oncol 2015 [Epub]. http://dx.doi.org/10.1245/s10434-015-4527-y

\section{SARGINIO LIMFMAZGIO BIOPSIJA PO NEOADJUVANTINĖS CHEMOTERAPIJOS DÉL KRŪTIES VE்ŽIO. RYŽTIS VERTA! \\ A. Čižauskaitė, D. Petrauskas, D. Šimčikas, A. Česas}

Raktažodžiai: krūties vėžys, sarginis limfmazgis, neoadjuvantinè chemoterapija, pažasties limfmazgių pašalinimas.

Santrauka

Tikslas. İvertinti numanomą pacienčių, sergančių krūties vėžiu, procentą, kurios būtų tinkamos sarginio limfmazgio biopsijai (SLB) po neoadjuvantinès chemoterapijos (NAC) Klaipėdos unversitetinès ligoninès Krūtų chirurgijos sektoriuje.

Ivadas. Nors SLB yra standartinis metodas pažasties limfmazgių būklei ịvertinti, naudojamas ankstyvo krūties vėžio atveju esant kliniškai nepakenktiems limfmazgiams pažastyje, šios procedūros panaudojimas po NAC išlieka kontroversiškas. Pažasties limfmazgių pašalinimas (PLP) yra priimtinas chirurginis pasirinkimas visoms ligonėms po NAC neatsižvelgiant ị pirminę sritinių limfmazgių būklę. PLP yra susijęs su reikšmingai didesniu sergamumu ir komplikacijų skaičiumi. NAC panaudojimas auga kasmet, ir šiandien ji skiriama ne tik lokaliai pažengusio krūties vėžio atveju, bet ir ankstyvose jo stadijose, todèl yra būtinos racionalios SLB indikacijos po NAC.

Metodai. 163 krūties vėžio, gydyto NAC, atvejai buvo ịtraukti ị šią studiją. Po taikytos NAC visoms pacientèms buvo atlikta PLP operacijos dèl krūties vèžio metu.

Rezultatai. Prieš skiriant NAC, kliniškai nepakenkti pažasties limfmazgiai buvo nustatyti 21 atveju (13\%), pakenkti pažasties limfmazgiai 141 atveju (87\%). İvertinus limfmazgių būklę po operacijos, pN0 kliniškai nepakenktų limfmazgių grupeje buvo nustatyta 21 pacientei (100\%). Tuo tarpu kliniškai pakenktų limfmazgiu grupeje pN0 buvo nustatytas 63 (44,7\%), o pN+ 78 $(55,3 \%)$ atvejams.

Išvados. SLB turètų visuomet būti atlikta prieš ar po NAC esant kliniškai nepakenktiems pažasties limfmazgiams. Esant kliniškai pakenktiems limfmazgiams prieš NAC, tinkamiausia chirurginė technika turètų būti pasirinkta siekiant užtikrinti šios procedūros saugumą.

Adresas susirašinèti: agne.cizauskaite@ku.lt

Gauta 2016-11-02 